\title{
Development of Steelmaking Process for Stainless Steel by Top and Bottom Blowing with Coke Addition in Converter*
}

\author{
By Noriyuki MASUMITSU,** Ryutatsu TANAKA,*** Takashi INOUE,*** \\ Shingo SATO*** and Kiyoshi TAKASHIMA***
}

\begin{abstract}
Synopsis
At Muroran Works, Nippon Steel Corporation, stainless steel has been produced by the LD-RH.OB process since 1972. This process has recenlly been improved by introducing the hot metal dephosphorization treatment and the top and bottom combination blowing of a LD converter. This paper shows the results when stainless steel scrap is used for the stainless steelmaking process by the addition of carbonaceous materials as an auxiliary heat source in the top and bottom blowing converter.

The results obtained are as follows:

(1) No significant difference in the heat efficiency is observed between the bottom injection of coke breeze and the top feeding of lump coke in the converter.

(2) The most effective way to high $\mathrm{Cr}$ yield is the additions of SUS scrap first separately before of $\mathrm{HC}-\mathrm{FeCr}$.

(3) The bottom gas injection acceralates the reactions to the thermodynamic equilibrium. For example, the $\left(\mathrm{Cr}_{2} \mathrm{O}_{3}\right)$ content in the slag at the turn down is significantly lower than that in the conventional converter.

(4) The contents of [S] and [N] in molten steel at the turn down in the $L D$ refining process increase with the addition of coke through the nitrogen bottom blowing. These impurity contents can be reduced to the normal level in the succesive $R H$ refining.
\end{abstract}

\section{Introduction}

The "hot metal pretreatment/combination blowing " process has become the main stream of the converter steelmaking technology for the integrated steelmakers. ${ }^{11}$

In stainless steel refining, particularly in the converter/vacuum decarburization process, efforts have been also made to introduce the single slag practice through the use of dephosphorized hot metal and to enhance the reduction refining through the combination blowing. ${ }^{2-5)}$ At Nippon Steel's Muroran Works, where stainless steels are produced by the LD-RH.OB process, ${ }^{6)}$ the various improvements such as process simplification and the realization of low-phosphorus stainless steel have been made through the introduction of hot metal dephosphorization. $\left.{ }^{7}\right)$

Tests have recently been conducted in the new steelmaking process which uses stainless steel scrap as a source of chromium, and small lump cokes and coke breezes as a heat source for scrap melting. This report contains the metallurgical characteristics of the melting of stainless steel scrap by the carbonaceous materials in the combined-blown converter and its effects on the product quality.

\section{Manufacturing Process and Its Features}

Figure 1 shows the stainless steel production by the LD-RH.OB process developed at Muroran Works.
The operational conditions of the hot metal pretreatment, the converter and the RH degassing equipment are given in Table 1. The stainless steel manufacturing process consists of the following three steps.

(1) Hot Metal Pretreatment

Desiliconization is performed by injecting oxygen gas through the injection lance. After the removal of the desiliconization slag, dephosphorization is performed by injecting the $\mathrm{CaO}-\mathrm{CaF}_{2}$ powder as a dephosphorizing flux, together with oxygen gas and mill scales as oxidizers, through the injection lance. When an extra-low-sulfur hot metal is needed, desulfurization is further carried out by using an $\mathrm{Na}_{2} \mathrm{CO}_{3}$ flux. With these pretreatments, the hot metal with $[\mathrm{P}] \leq 0.015 \%$ and $[\mathrm{S}] \leq 0.007 \%$ is obtained.

(2) Chromium Melting in the Converter

The hot metal and high-carbon ferro-chromium (HC-FeCr) are added into the vessel for the decarburization. Since the refining is intended during the high carbon content at the high temperature in the converter to minimize the oxidation loss of chromium. the end-point carbon and the temperature are set to be $0.60 \sim 0.70 \%$ and $1780 \sim 1800$, respectively.

(3) $\mathrm{RH} \cdot \mathrm{OB}$ Treatment

The liquid steel tapped from the converter is preferentially decarburized without the oxidation of chromium., by the injection of oxygen gas under the reduced pressure in the $\mathrm{RH}$ degassing equipment. After the decarburization period, silicon and aluminum. are added for the deoxidation and the composition adjustment.

\section{Test Method for the Use of Stainless Steel Scrap in the Converter}

Figure 2 shows the outline of the equipment used in the tests. Stainless steel scrap was charged into the 120-t combined blown converter with the aid of scrap bags. The cokes used as a heat source for melting the scrap are of small lump and breeze, which are not suitable for the blast furnace. The lump coke was charged through the alloy addition chute, whereas the coke breeze was injected through the nozzles on the vessel bottom. The chemical composition and size of the coke added are given in Table 2. The stainless steel scrap used included the crops from the continuous casting process, the scrap from the slabbing mill, the both are almost in the as-generated forms.

\footnotetext{
* Based on the papers presented to the 108th ISIJ Meeting, October 1984, S1015 and S1016, at Hiroshima University in Hiroshima. Manuscript received on June 11, 1985; accepted in the final form on December 6, 1985. (C) 1986 ISIJ

** Carnegie-Mellon University, Pittsburgh, PA 15213, U.S.A. On leave from Muroran Works, Nippon Steel Corporation.

*** Muroran Works, Nippon Steel Corporation, Nakamachi, Muroran 050.
} 
Hot Metal Pretreatment

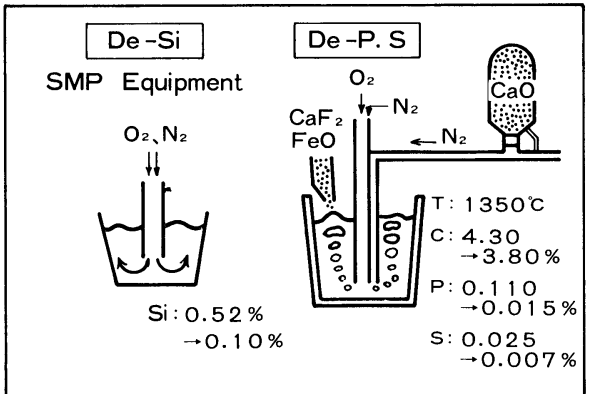

Fig. 1. Production of stainless steel by the LD-RH.OB process.
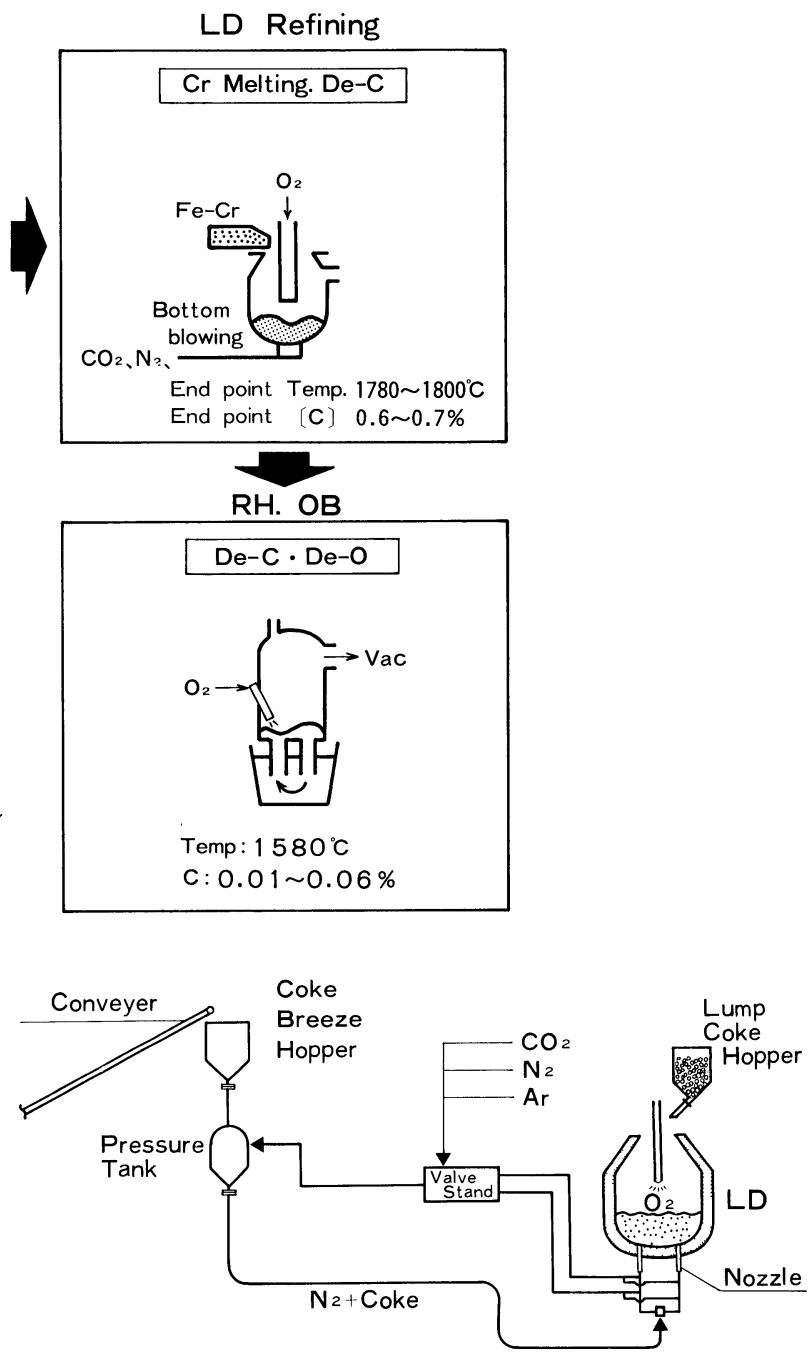

Fig. 2. Schematic flow diagram of coke addition in LD converter.

Table 2. Chemical composition and size of coke.

\begin{tabular}{|c|c|c|c|c|c|c|c|}
\hline \multicolumn{6}{|c|}{ Chemical composition (\%) } & \multicolumn{2}{|c|}{ Size $(\mathrm{mm})$} \\
\hline $\mathrm{C}$ & $\mathrm{S}$ & $\mathrm{P}$ & $\mathrm{N}$ & V.M. & Ash & $\begin{array}{l}\text { Lump } \\
\text { coke }\end{array}$ & $\begin{array}{c}\text { Coke } \\
\text { breeze }\end{array}$ \\
\hline 87.0 & 0.48 & 0.06 & 0.2 & 1.5 & 10.5 & $20 \sim 30$ & $0.1 \sim 0.8$ \\
\hline
\end{tabular}

\section{Test Results}

\section{Scrap Melting Capacity of the Carbonaceous Materials}

Various reports are available on the addition of carbonaceous materials into the converter as the heat source. ${ }^{8-10)}$ In these papers, the effects of the carbonaceous materials upon the increases in the liquid steel temperature in the converter are reported to be in the range of $5 \sim 7^{\circ} \mathrm{C} / \mathrm{kg}$ - $\mathrm{C}$, depending on their kinds and the sizes, the carbon concentration in the steel bath, the intensity of the bottom sitrring, the postcombustion rate of $\mathrm{CO}$ gas and the other factors. The enthalpy change in the liquid steel by the addition of the carbonaceous materials is calculated in Appendix mainly on the basis of sensible heat for heating the carbonaceous materials from the room 
temperature up to the bath temperature, the heat of carbon solution, and the heat of carbon oxidation. When the coke containing $87 \% \mathrm{G}$ is used as a carbonaceous material, the amounts of heat generated by the lump coke charged into the vessel and the coke breeze injected through the vessel bottom are calculated to be $5.7^{\circ} \mathrm{C} / \mathrm{kg}$-coke and $5.3^{\circ} \mathrm{C} / \mathrm{kg}$-coke, respectively.

Figure 3 shows the relationship between the amount of coke added and the stainless steel scrap ratio. With an approximately $30 \mathrm{~kg} / \mathrm{t}$ of coke addition, the approximately $10 \%(100 \mathrm{~kg} / \mathrm{t})$ of stainless steel scrap was melted, with no scrap left unmelted. No significant difference in the melting capacity was observed between the lump coke and the coke breeze, contrary to the expected difference in the melting capability between them because of longer melting time required for the lump coke than for the coke breeze and therefore the lower yield for the lump coke. This is probably due to the fact that the lump coke can also completely melt within the scrap melting time of $7 \sim 10 \mathrm{~min}$, and this nearly $100 \%$ yield is proved by the oxygen and carbon balance at the blow off point of the scrap melting period. According to Fig. 3, the coke has a scrap melting capability of $3.0 \sim 3.5 \mathrm{~kg}$ per unit weight of coke $\left(5.4 \sim 6.3^{\circ} \mathrm{C} / \mathrm{kg}\right.$-coke, assuming that $1 \%$ of scrap ratio is equivalent to $18{ }^{\circ} \mathrm{G}$ ) in fair agreement with the calculated values in Appendix and with the reported values. ${ }^{8-10)}$

\section{Heat Efficiency with and without Coke Addition}

Figure 4 shows the relationship between the amount of the coke added and the partition of the heat input into the steel, the slag the out gas, etc. With increase in the amount of the coke added, the partition of the heat, $\eta_{H}$ to the molten steel (broken line in the figure) decreases. With $25 \mathrm{~kg} / \mathrm{t}$ of the coke added, it lowers by $14 \%$. This is because the total heat input in the converter increases with the coke consumption whereas the heat output to the molten steel is kept constant as the blow-end temperature in the converter is almost constant. The 120-t converter at Muroran No. 2 steelmaking plant is of the boiler type where the heat of the secondary oxidation reaction of carbon is recovered as steam. This steam recovery and the

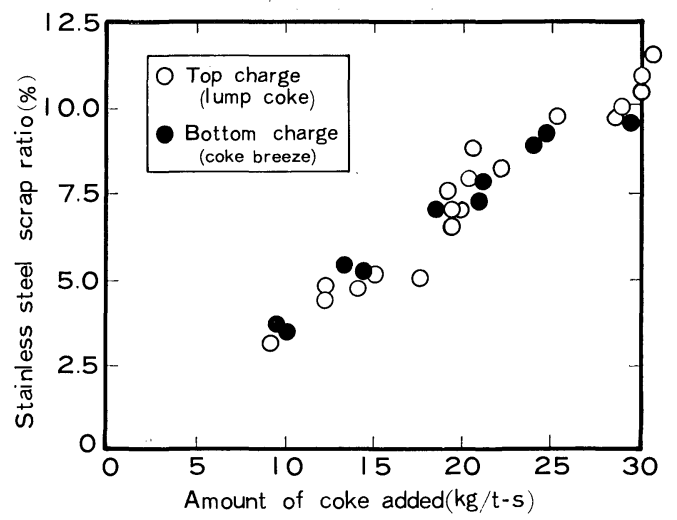

Fig. 3. Relationship between amount of coke added and the stainless steel scrap ratio. sensible heat of steel are the effective energy. A coke addition of $25 \mathrm{~kg} / \mathrm{t}$ causes an approximately $4 \%$ drop in the effective energy as shown in Fig. 4.

This decrease is attributable, firstly to the increase in the loss of the waste gas sensible heat with the increase in the amount of the waste gas, secondly to the loss of the sensible heat associated with the increase in the amount of the slag due to the ash content $(15 \sim 17 \%)$ of the coke, and thirdly to the increase in the radiation heat from the furnace in the prolonged blowing time caused by the increase in the amount of the coke added.

Figure 5 shows the typical heat balances in the stainless steel refining with and without the coke addition. In the heat with a coke addition of $24 \mathrm{~kg} / \mathrm{t}$, the steam generation is more than twice, and the loss as the sensible heat of the waste gas is more than one and half times bigger than that without the addition. The heat efficiency including the steam recovery, is $58.6 \%$ with the coke addition, and $60.5 \%$ without the addition.

\section{Scrap Melting Patterns}

Table 3 shows the scrap melting patterns. In the conventional practice, $\mathrm{HC}-\mathrm{FeCr}$ is added in two equal lots to prevent oxygen blowing at the low temperature. On the present tests, on the other hand, three scrap melting methods were compared. For Method A, HC-FeCr, stainless steel scrap, and coke were added simultaneously at the initial stage of the blowing.

Although this method allows a short operation time, it inherently includes the oxygen blowing at the low temperature and the low carbon condition. Method B consists of an addition of coke at the initial stage of the blowing and a subsequent simultaneous addition of $\mathrm{HC}-\mathrm{FeCr}$ and stainless steel scrap in the intermediate stage. This method is characterized by the oxygen blowing at the high temperature in the high carbon region since it consists of an advance addition of coke and the subsequent separate additions of $\mathrm{HC}-\mathrm{FeCr}$ and stainless steel scrap.

Figure 6 shows the relationship between the stain-

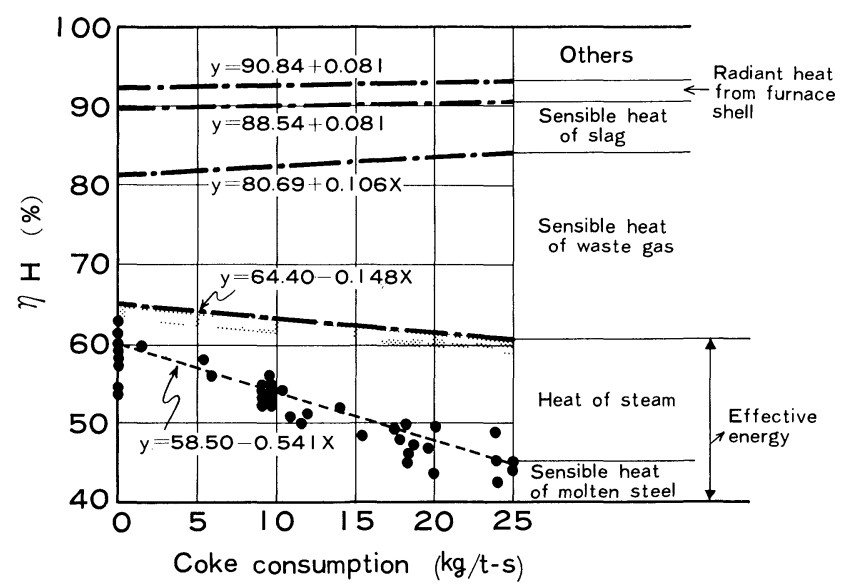

Fig. 4. Relationship between the partition of heat and coke consumption. 


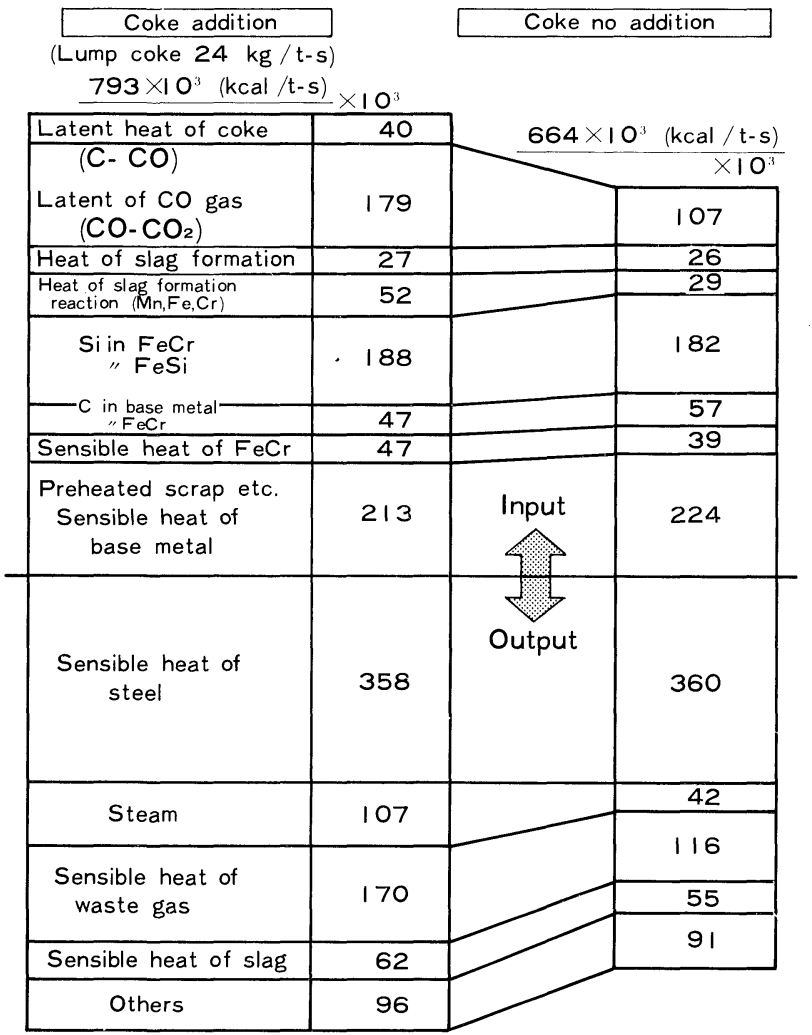

Fig. 5. Heat balances in SUS refining with and without coke addition.

Table 3. Patterns of scrap and HC-FeCr melting.

\begin{tabular}{|c|c|c|}
\hline pattern. & $\begin{array}{l}\text { Start } \\
\nabla\end{array}$ & Characteristics \\
\hline $\begin{array}{l}\text { Conven- } \\
\text { tional }\end{array}$ & $\begin{array}{lll} & \mathrm{FeCr} & \mathrm{FeCr} \\
\end{array}$ & - Divided charge of $\mathrm{FeCr}$ \\
\hline A & $\begin{array}{l}\text { Coke } \\
\text { Scrap } \\
\text { FeCr }\end{array}$ & $\begin{array}{l}\text { - Charging together of } \\
\mathrm{FeCr} \text { and Scrap } \\
\text { - Melting in low temp. and } \\
\text { low [\% C ] range }\end{array}$ \\
\hline B & $\begin{array}{l}\text { Coke } \\
\text { Scrap } \\
\text { FeCr }\end{array}$ & $\begin{array}{l}\text { - Charging together } \\
\mathrm{FeCr} \text { and Scrap } \\
\text { - Melting in low temp. and } \\
\text { high [\% }] \text { range }\end{array}$ \\
\hline c & $\begin{array}{l}\text { Coke } \\
\text { Scrap } \\
\qquad \mathrm{FeCr} \quad \mathrm{FeCr}\end{array}$ & $\begin{array}{l}\text {-Separate charging of } \\
\text { Scrap and } \mathrm{FeCr} \\
\text { - Melting in high temp. } \\
\text { and high (\%C } \text { ] range }\end{array}$ \\
\hline
\end{tabular}

less steel scrap ratio and the $\mathrm{Cr}_{2} \mathrm{O}_{3}$ content in the slag at the blow-end.

For Methods $\mathrm{A}$ and $\mathrm{B}$, the $\mathrm{Cr}_{2} \mathrm{O}_{3}$ content in the slag increases with increase in the stainless steel scrap ratio. For Method $\mathrm{G}$, however, the $\mathrm{Cr}_{2} \mathrm{O}_{3}$ content in the slag remains constant at the range of $4 \sim 8 \%$ even when the stainless steel scrap ratio is increased. This can be qualitatively understood by the schematic diagram, Fig. 7 where the trajectory of the temperature and the carbon content is depicted for each pattern in the $\mathrm{C}-\mathrm{Cr}$-temperature equilibrium curve. ${ }^{11)}$ It is clear from the figure that for Method $\mathrm{C}$ the steel experiences less time to go through the region where the chromium oxidation is predicted by the thermodynamic calculation, thus resulting in the less chromi-

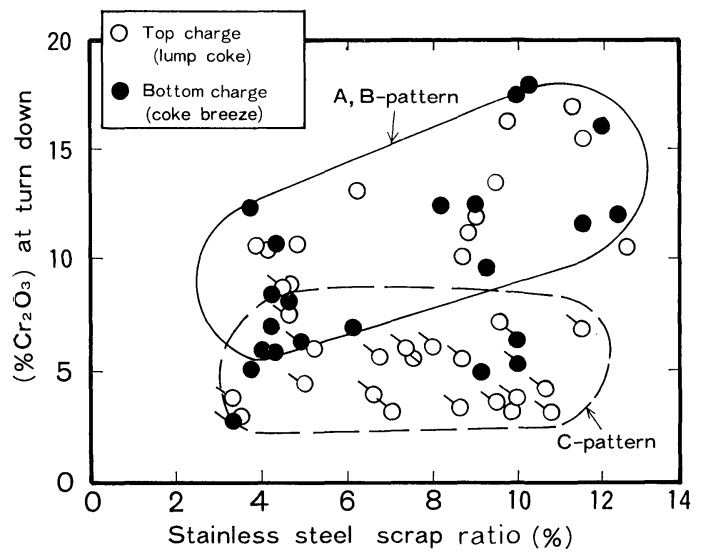

Fig. 6. Effect of scrap melting pattern of $\left(\% \mathrm{Cr}_{2} \mathrm{O}_{3}\right)$ at turn down.

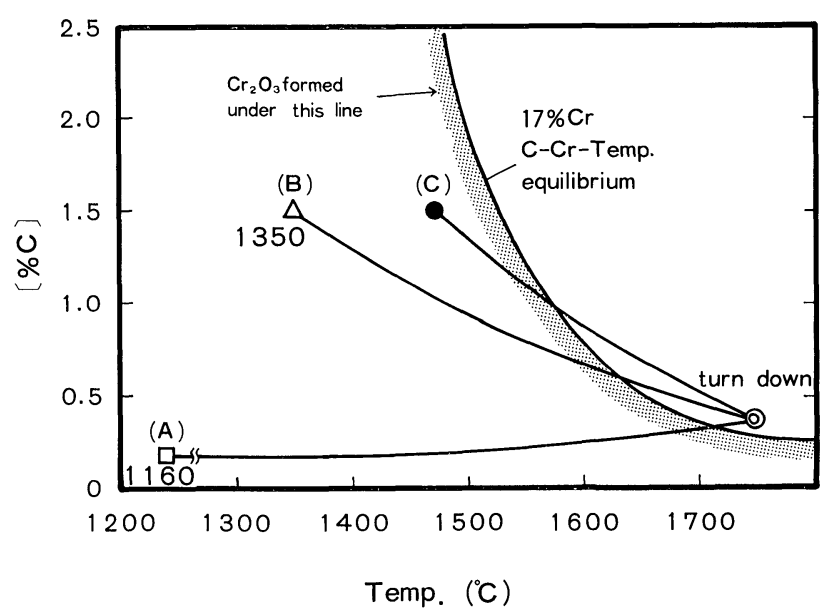

Fig. 7. Schematic diagram of refining pattern in $\mathrm{C}-\mathrm{Cr}-$ temperature equilibrium curve.

um oxidation in accord with the experimental results shown in Fig. 6.

\section{The Effect of Bottom Stirring}

1. Improvement of Decarburization Reaction

Figure 8 shows the relationship between [C] and $\left(\mathrm{Cr}_{2} \mathrm{O}_{3}\right)$ at the blow-end for the conventional LD and the combined-blown LD converters. In a highcarbon region of $[\mathrm{C}] \geq 0.60 \%,\left(\mathrm{Cr}_{2} \mathrm{O}_{3}\right)$ remains at the same level of $3 \sim 7 \%$ for both the top and the combination-blown practices. In an low-carbon region of $[\mathrm{G}]<0.6 \%$, however, the bottom blowing at a flow rate of over $0.20 \mathrm{Nm}^{3} / \mathrm{t}-$ min remarkably decreases the $\left(\mathrm{Cr}_{2} \mathrm{O}_{3}\right)$ content in the slag. For example the $\left(\mathrm{Cr}_{2} \mathrm{O}_{3}\right)$ in the slag at the blowing end of SUS430 steel with the [G] content of $0.25 \%$ is approximately $10 \%$ for the combination blowing whereas approximately $20 \%$ for the top blowing. Kai et al..$^{5)}$ reported that the combination blowning has an effect of the reducing $\left(\mathrm{Cr}_{2} \mathrm{O}_{3}\right)$ in the slag even at such a low flow rate of the bottom-blown gas as $0.06 \mathrm{Nm}^{3} / \mathrm{t}$-min or below. The present tests, however, show that the effect of the bottom blowing becomes pronounced at the flow rates over $0.20 \mathrm{Nm}^{3} / \mathrm{t}$ min. The need for the higher flow rate of the bottom 


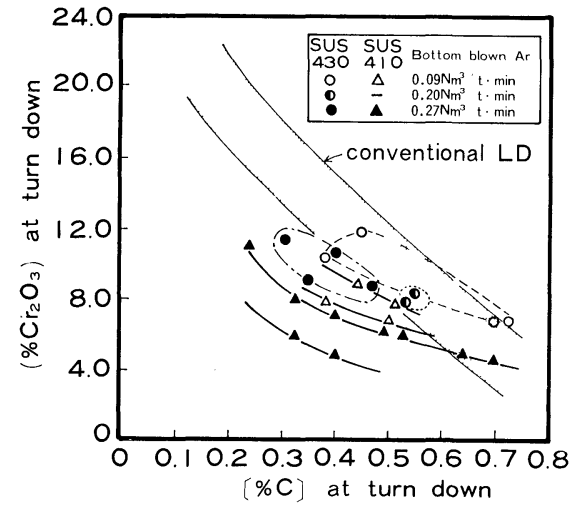

Fig. 8. Influence of bottom blowing gas on the relationship between $[\% \mathrm{C}]$ and $\left(\% \mathrm{Cr}_{2} \mathrm{O}_{3}\right)$ at turn down.

gas in our case may be attributable to the higher inhomogeneity of the chromium distribution in the bath due to the use of cold $\mathrm{HC}-\mathrm{FeCr}(\mathrm{Cr} \approx 52 \%)$ as the source of chromium.

For the EF-LD process used by Kai et al., the decarburization is performed for the high-carbon, highchromium. liquid steel that has been prepared by the proceeding EF process.

\section{Elimination of Unmelted Scrap}

In the present study using the combined blown converter, even when $10 \sim 12 \mathrm{t} /$ heat of stainless steel scraps weighing $300 \sim 500 \mathrm{~kg} /$ piece were added to the base metal at approximately $1650{ }^{\circ} \mathrm{C}$, no unmelted scrap was observed after 8 to $10 \mathrm{~min}$ of the oxygen blowing. In the conventional top-blown converter, on the other hand, it has been experienced that the refining time of 8 to $10 \mathrm{~min}$ is not enough to the complete melting of such amount and size of the scraps even if the thermal balance is maintained at a proper level. This shows that the bottom strirring is quite effective to eliminate the unmelted scraps.

\section{Reduction of $\left(\mathrm{Cr}_{2} \mathbf{O}_{3}\right)$}

As noted earlier, one of the objectives of the intense bath strirring by the bottom gas blowing is to promote the reduction of the chromium. oxide formed during the melting and decarburization periods. Figure 9 shows the relationship between the $\left(\mathrm{Cr}_{2} \mathrm{O}_{3}\right)$ in the slag at the blow-end and after the reduction. With an addition of ferrosilicon as the reducing agent at constant levels of $0.5 \sim 1.0 \mathrm{~kg} / \mathrm{t}$, the $\left(\mathrm{Cr}_{2} \mathrm{O}_{3}\right)$ in the slag after the reduction is 1.0 to $1.5 \%$ lower in the combined-blown converter, compared with that in the top-blown converter.

Figure 10 shows a comparison of the relationship between the [C] and the $\left(\mathrm{Cr}_{2} \mathrm{O}_{3}\right)$ at the end of the reduction refining in the conventional and the combined-blown converters. With the same [G] value, the $\left(\mathrm{Cr}_{2} \mathrm{O}_{3}\right)$ in the combined-blown converter is approximately $2 \%$ lower than that in the topblown converter. In other words, the combinedblown converter is capable of the reducing blow-end [C] by $0.2 \%$ at the same chromium loss, thus reducing the load for the subsequent decarburization in the RH unit.

\section{Optimum Bottom Stirring Power}

In order to determine the optimum reduction refin-

$$
\gamma_{\text {Red }}=\frac{\left(\% \mathrm{Cr}_{2} \mathrm{O}_{3}\right) \text { turn down }-\left(\% \mathrm{Cr}_{2} \mathrm{O}_{3}\right) \text { after reduction }}{\left(\% \mathrm{Cr}_{2} \mathrm{O}_{3}\right) \text { turn down }}
$$

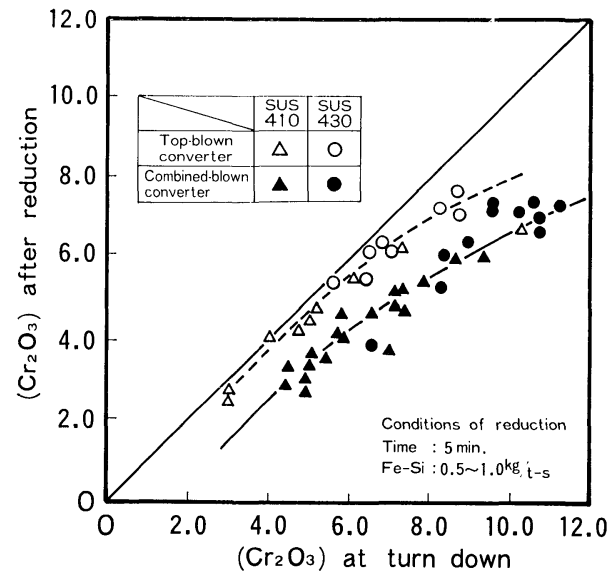

Fig. 9. Relationship between $\left(\% \mathrm{Cr}_{2} \mathrm{O}_{3}\right)$ at turn down and $\left(\% \mathrm{Cr}_{2} \mathrm{O}_{3}\right)$ after reduction.

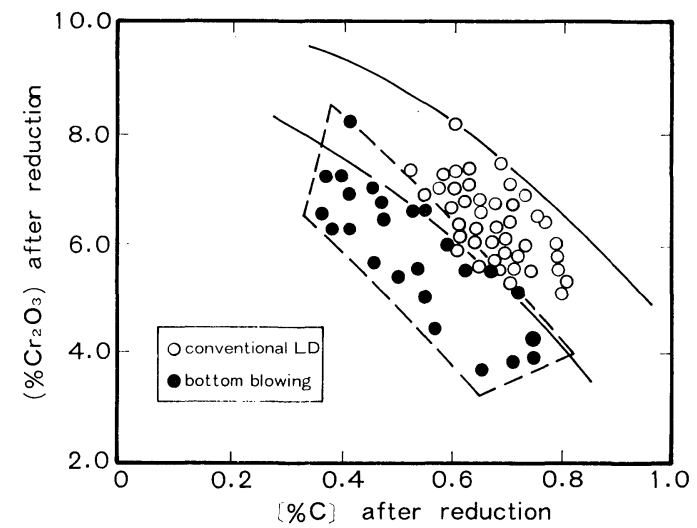

Fig. 10. Relationship between $\left(\% \mathrm{Cr}_{2} \mathrm{O}_{3}\right)$ in slag and $[\%$ $\mathrm{C}]$ in molten steel after reduction.

ing conditions, the total stirring energy is calculated from the following two equations.

$$
\begin{aligned}
\varepsilon_{B} & =\frac{0.0285 \times Q_{B} \times 10^{3} \times T}{W} \log \left(1+\frac{L_{0}}{1.48}\right)(\mathrm{W} / \mathrm{t}) \\
\ldots \ldots \ldots \ldots \ldots \ldots \ldots \ldots \ldots \ldots \ldots \ldots \ldots \ldots \ldots \ldots \ldots \ldots \ldots \ldots \ldots \ldots \ldots \ldots \ldots \ldots \ldots \ldots \ldots \ldots \ldots \ldots \ldots \ldots \ldots \ldots \ldots \ldots & (1)
\end{aligned}
$$

where, $\varepsilon_{B}$ : physical stirring energy $(\mathrm{W} / \mathrm{t})$

T: steel bath temperature $\left({ }^{\circ} \mathbf{K}\right)$

$L_{0}:$ steel bath depth $(\mathrm{cm})$

$E:$ total stirring energy $(\mathrm{J} / \mathrm{t})$

$Q_{B}$ : flow rate of bottom blowing gas $\left(\mathrm{Nm}^{3} /\right.$ $\min$ )

$W$ : weight of liquid steel $(\mathrm{t})$

$t$ : reduction time $(\mathrm{sec})$.

Figure 11 shows the relationship between the total stirring energy calculated from the above equations and the efficiency of ferrosilicon as the reducing agent for $\left(\mathrm{Cr}_{2} \mathrm{O}_{3}\right)$. The reduction efficiency first increases with increase in the total stirring energy and then saturates at the total stirring energy of about $7 \times$ $10^{5} \mathrm{~J} / \mathrm{t}$. It is found that, at a bottom-blown gas flow rate of $0.15 \mathrm{Nm}^{3} / \mathrm{t}$-min, for example, approximately 


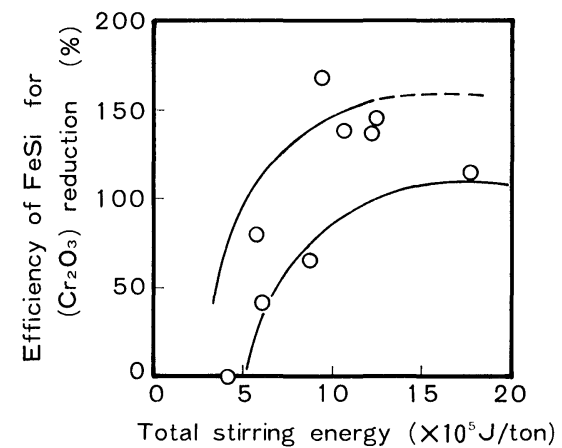

Fig. 11. Effect of bottom stirring on the $\left(\mathrm{Cr}_{2} \mathrm{O}_{3}\right)$ reduction efficiency by $\mathrm{FeSi}$.

4.5 miin is sufficient for the reduction refining.

Figure 12 shows the changes in the chemical composition of the slag during the reduction refining. Almost $70 \%$ of the $\left(\mathrm{Cr}_{2} \mathrm{O}_{3}\right)$ is reduced in $2 \mathrm{~min}$ and the value of the $\left(\mathrm{Cr}_{2} \mathrm{O}_{3}\right)$ becomes virtually constant after $6 \mathrm{~min}$. The value of the (T.Fe) behaves similarly to of the $\left(\mathrm{Cr}_{2} \mathrm{O}_{3}\right)$. The value of the $(\mathrm{MgO})$, on the other hand, increases as the reduction reaction proceeds due to the refractory wear enhanced by the reduced basicity which is caused with $\mathrm{SiO}_{2}$ formation by the reduction reaction and also enhanced by the bottom stirring.

\section{Effects of Coke Addition on Steel Quality}

\section{Behavior of $[\mathbf{S}]$}

\section{(1) Sulfur}

Judging from the approximately $0.5 \% \mathrm{~S}$ content of the coke used as the heat source and the low desulfurization ratio in the converter, most of the sulfur is considered to be captured in the liquid steel. Figure 13 shows a typical example of the sulfur balance when $24 \mathrm{~kg} / \mathrm{t}$ of the coke is added.

Approximately $60 \%$ of the input sulfur comes from the coke and $17 \%$ from the $\mathrm{HC}-\mathrm{FeCr}([\mathrm{S}] \approx$ $0.10 \%$ ). This means that approximately $80 \%$ of sulfur is brought into the liquid steel from the sources other than the base metal. Consequently, desulphurization of the liquid steel after the refining in the converter is essential to ensure the sulfur concentration obtained so far by the conventional process.

(2) Desulfurization during Oxygen Blowing in Converter

Figure 14 shows the relationship between the slag basicity and the desulfurization ratio during the oxygen blowing. The desulfurization ratio increases with increase in the slag basicity. However, the optimum slag basicity is 1.3 to 1.4 in terms of the yield of chromium, so much desulfurization during the oxygen blowing can not be expected.

(3) Desulfurization during Reduction Period

Figure 15 shows the relationship between the [S] at the end point of the oxidizing refining and the desulfurization ratio in the reduction refining. The desulfurization ratio increases with increase in the blow end [S] and the slag basicity. The effect of the basicity is remarkable for the case when the

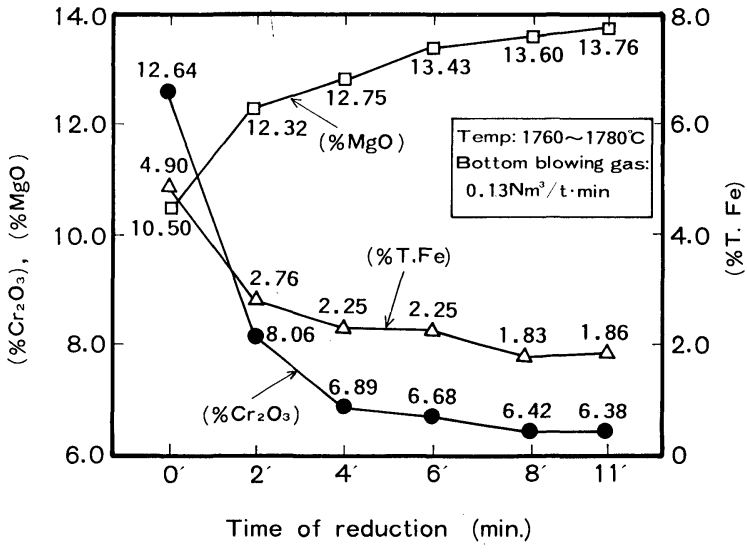

Fig. 12. Change of slag composition during reduction by bottom blowing.

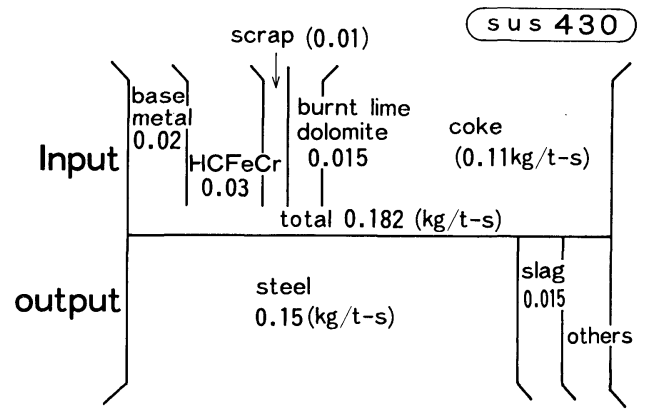

Fig. 13. Sulfur balance in LD refining.

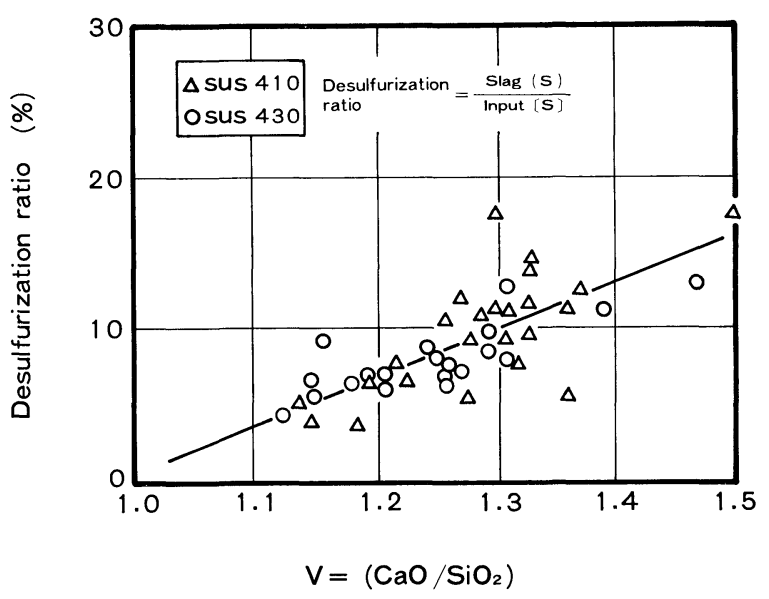

Fig. 14. Relationship between basicity and desulfurization ratio in LD refining.

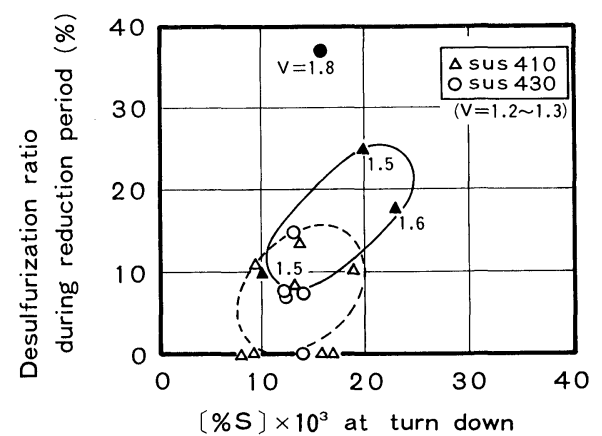

Fig. 15. Desulfurization ratio during reduction period. 
desulfurization ratio is improved to $37 \%$ by increasing the basicity up to 1.8. To improve the desulfurization ratio during the reduction refining, the liquid steel is better to be fully killed by the [Si] of $0.4 \sim 0.6 \%$.

According to the report on the operation data from the AOD vessel, ${ }^{16)}$ desulfurization is effectively accomplished in the high-[Si], low-[O] region, i.e., the end-point temperature of $1745{ }^{\circ} \mathrm{C}[\mathrm{Si}]=0.66 \%$, $[\mathrm{O}]=160 \mathrm{ppm}$ after the chromium reduction; and end-point temperature of $1690^{\circ} \mathrm{C},[\mathrm{Si}]=0.52 \%$, [O] $=40 \mathrm{ppm}$ after the desulfurization, respectively. On the other hand, in the LD- $\mathrm{RH}$. OB process at Muroran Works, a vacuum decarburization by $\mathrm{RH}$ is conducted after the converter blowing. Figure 16 shows the relationship between the [Si] concentration in the steel before RH treatment and the oxygen efficiency for decarburization in the $\mathrm{RH}$ process. As the [Si] concentration before the $\mathrm{RH}$ treatment increases, the oxygen efficiency for the decarburization decreases. To cope with this, the upper limit for the [Si] before the $\mathrm{RH}$ treatment has to be set at $0.15 \%$. So the refining in the converter is conducted at the elevated temperature to inhibit the oxidation loss of chromium, the [Si] content in the molten steel at the blow-end is in the range of $0.05 \sim 0.08 \%$. From the equations given below, the oxygen concentration is calculated to be $530 \sim 800 \mathrm{ppm}$ at $1780^{\circ} \mathrm{C},[\mathrm{Cr}]=$ $16.5 \%$ and $[\mathrm{G}]=0.5 \sim 0.8 \%$.

$$
\begin{aligned}
& \mathrm{C}+\mathrm{O} \rightarrow \mathrm{CO} \log K=\log \frac{P_{\mathrm{CO}}}{a_{\mathrm{C}} \cdot a_{\mathrm{O}}} \\
& =1160 / T+2003^{13-15)} \\
& e_{\mathrm{C}}^{\mathrm{c}}=0.298, e_{\mathrm{C}}^{\mathrm{o}}=-0.316, e_{\mathrm{C}}^{\mathrm{cr}}=-0.024 \\
& e_{\mathrm{o}}^{\mathrm{C}}=-0.421, e_{0}^{\mathrm{o}}=-1750 / \mathrm{T}=0.76, e_{0}^{\mathrm{Cr}}=-0.040
\end{aligned}
$$

For these reasons, the desulfurization during the reduction refining in the converter can not be expected.

In the present tests, therefore, the desulfurization is carried out by using a $\mathrm{CaO}-\mathrm{CaF}_{2}$ flux after the decarburization and the deoxidation in the RH. ${ }^{17)}$

\section{Behavior of Nitrogen}

The nitrogen content in the molten steel at the oxygen blow end in the present converter tests was in between $150 \sim 250 \mathrm{ppm}$, which was larger than that $(60 \sim 80 \mathrm{ppm})$ in the conventional process partly because the coke used contains $1.2 \% \mathrm{~N}$ and partly because $\mathrm{N}_{2}$ gas was used as the coke breeze carrier gas.

Figure 17 shows the behavior of nitrogen during the refining in the converter. The figure indicates that the denitrification reaction, together with the decarburization reactions, take place during the oxygen blow. It can be also seen that the nitrogen absorption proceeds when the blowing is interrupted for the scrap and $\mathrm{Fe}-\mathrm{Cr}$ addition. After the repeated increase and decrease, the nitrogen concentration at the end of the blowing becomes $150 \sim 250 \mathrm{ppm}$.

Figure 18 shows the yield of nitrogen gas in the converter. The yield of nitrogen gas at the end of the blowing decreases from 11 to $4 \%$ as the volume of bottom blown nitrogen gas increases. Nitrogen input includes $0.03 \%$ from the coke (with $25 \mathrm{~kg} / \mathrm{t}$ of coke containing $1.2 \% \mathrm{~N}$ ) and $0.2 \sim 0.4 \%$ from the bottom-blown gas $\left(1.2 \sim 2.8 \mathrm{Nm}^{3} / \mathrm{t}\right)$. Thus the nitrogen input from the coke stands for approximately $10 \%$ of the total input and, therefore, causes no problem of the high nitrogen concentration for virtually all stainless steel grades.

Figure 19 shows the changes in the nitrogen concentration during the $\mathrm{RH}$ refining. As can be seen in the figure, even for a nitrogen concentration of $400 \mathrm{ppm}$ before the $\mathrm{RH}$ treatment, therefore, the

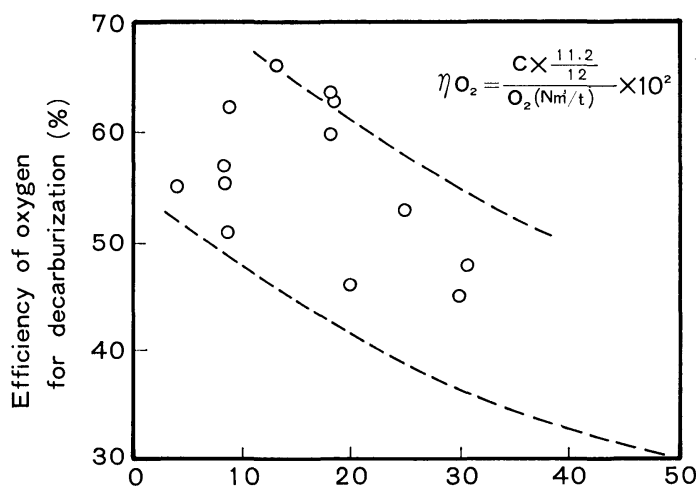

[Si at the start of $\mathrm{RH}$ treatment $\left(\times 10^{-2} \%\right)$

Fig. 16. Effect of [Si] content at RH start on the efficiency of oxygen for decarburization.

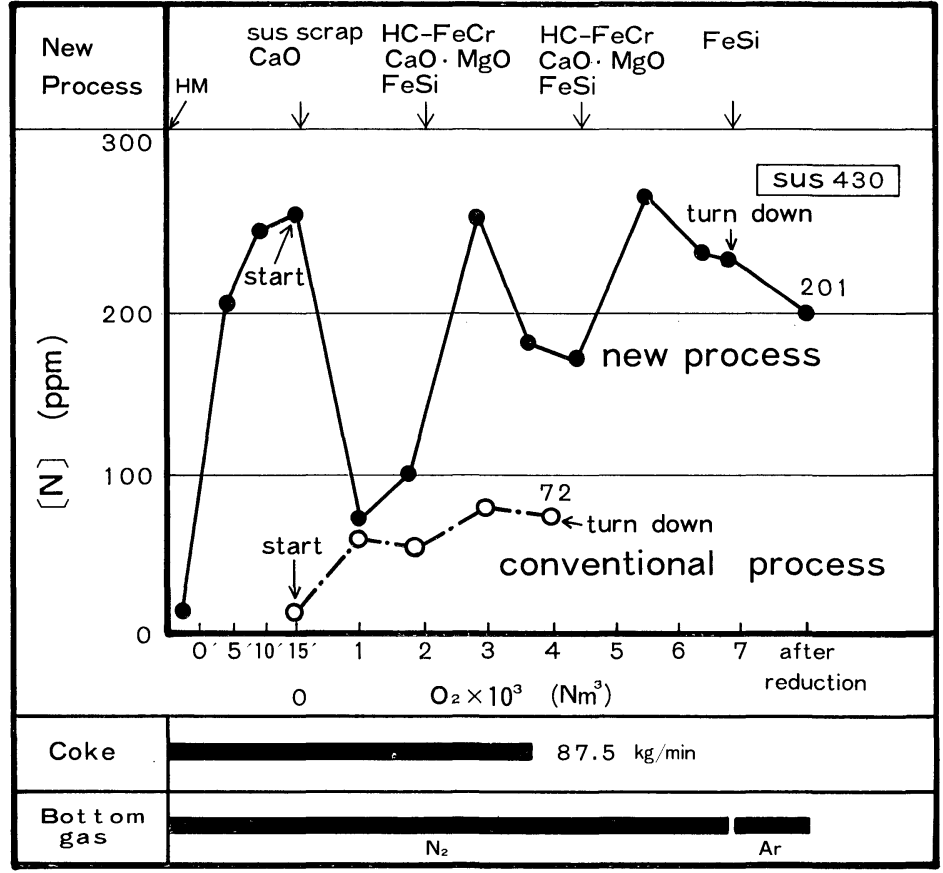

Fig. 17. Change of $[\mathrm{N}]$ in molten steel during LD blowing. 


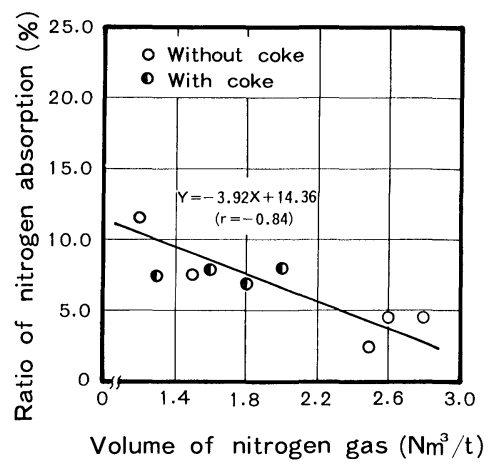

Fig. 18. Relationship between volume of nitrogen gas and ratio of nitrogen absorption in LD converter.

concentration can be reduced to less than $150 \mathrm{ppm}$ after the $\mathrm{RH}$ refining by ensuring the sufficient decarburization. Thus, the nitrogen absorption from the coke and the bottom. blowing nitrogen gas can be offset by degassing in the RH.

Stainless steels with a nitrogen specification of $[\mathrm{N}] \leq 100 \mathrm{ppm}$ can be successfully produced by using gases other than $\mathrm{N}_{2}$, such as $\mathrm{CO}_{2}$ and $\mathrm{Ar}$, for the bottom-blown gas in the combined-blown converter.

\section{Conclusion}

(1) No significant difference in scrap melting capacity has been observed between the bottom injection of coke breeze and the top feeding of lump coke as the heat source. The scrap melting capacity of the coke is $3.0 \sim 3.5 \mathrm{~kg}$-scrap $/ \mathrm{kg}$-coke (5.4 $6.3^{\circ} \mathrm{C} / \mathrm{kg}$-coke).

(2) With increase in the coke addition, the thermal efficiency of the converter is lowered, e.g., approximately $4 \%$ low at the coke addition of $25 \mathrm{~kg} / \mathrm{t}$ when the steam recovery is included in the effective energy.

(3) The optimum scrap melting pattern for refining stainless steel is the one in which carbonaceous materials are added before solid iron source ( $\mathrm{HC}_{-}$ FeCr, stainless steel scrap), and the stainless steel scrap and the HC-FeCr are separately added. This practice allows the oxygen blowing to be carried out under the high-temperature and high-carbon condition.

(4) Bottom blowing is effective in improving the decarburization reaction in the low-carbon region of $[\mathrm{C}] \leq 0.6 \%$. Furthermore, the reactions between the $\left(\mathrm{Cr}_{2} \mathrm{O}_{3}\right)$ in the slag and the reducing elements can be enhanced by ensuring stirring energy $E \geq 7 \times 10^{5}$ $\mathrm{J} / \mathrm{t}$ during the reduction refining.

(5) The increase in the sulfur and nitrogen contents caused by the coke and the bottom-blown gas can be compensated by the subsequent RH refining process, thus making the same quality of the stainless steel as that in the conventional ones.

According to the results obtained by the test described in this report, the new process has been put into operation since 1983. In the new process lump coke is added in $10 \%$ SUS scrap melt from the top of the converter with the bottom blowing.

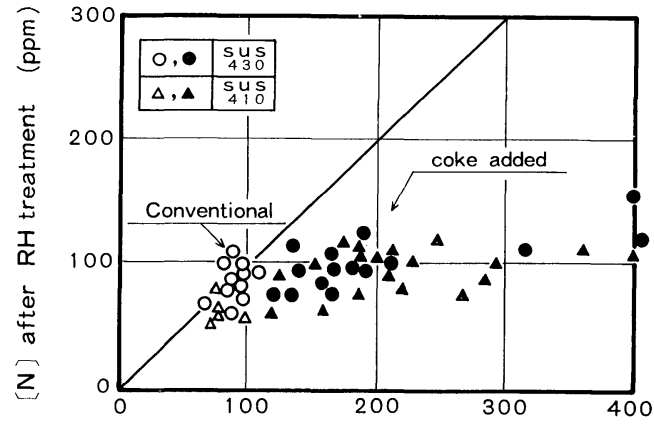

[N] before $\mathrm{RH}$ treatment (ppm)

Fig. 19. Nitrogen removal during $\mathrm{RH}$ treatment.

\section{REFERENCES}

1) T. Ueda, K. Marukawa and M. Anezaki: Tetsu-to-Hagané, 69 (1983), 24.

2) I. Tanaka, K. Kanekogi, U. Gondoh, T. Uchimura, T. Inatomi and M. Tsuchinaga: Tetsu-to-Hagané, 69 (1983), S143.

3) S. Murakawa, N. Satoh, T. Uchimura, H. Aoki, M. Tuchinaga and M. Kobayashi: Tetsu-to-Hagané, 70 (1984), S1017.

4) Kawasaki Steel Corp.: Report to the 67th Special Steel Comm., Joint Research Soc., ISIJ, March 1982.

5) T. Kai, F. Hoshi, Y. Uedate and T. Yamagami: Tetsu-toHagané, 70 (1984), 680.

6) Y. Kamii, S. Ohkubo and A. Etoh: Tetsu-to-Hagané, 63 (1977), 2064.

7) S. Ono, T. Itoh, S. Satoh, T. Inoue, N. Masumitsu and T. Hasegawa: Tetsu-to-Hagané, 68 (1982), S296; Trans. ISIJ, 22 (1982), B381.

8) Y. Ohnishi, M. Kawasaki, W. Takagi, Y. Igai, J. Katsuta and M. Aoki: Tetsu-to-Hagané, 70 (1984), S264.

9) Kawasaki Steel Corp.: Report to the 84th Steelmaking Comm., Joint Research Soc., ISIJ, March, 1983.

10) Karl Brotzmann: JOURNEES SIDERURGIOUES ATS, 1981, SESSION 8.

11) D. C. Hilty, H. P. Rassbach and W. Crafts: JISI, 180 (1955), 6, 116.

12) N. Nakanishi, T. Fujii and J. Szekely: Ironmaking Steelmaking, (1975), No. 3, 193.

13) The 19th Committee (Steelmaking), Japan Soc. Promotion of Science (JSPS), Recommended Equilibrium Values in Steelmaking Reactions, Nikkan Kogyo Shinbunsha, Tokyo, (1968).

14) Y. Kojima and K. Sano: Tetsu-to-Hagané, 50 (1964), 888.

15) T. Fuwa, S. Ban-ya and K. Suzuki: The 19th Committee (Steelmaking), Japan Soc. Promotion of Science (JSPS), Rep. No. 8132 (May, 1966).

16) K. Yamada, H. Higashi, T. Hiyama and K. Sugimura: Tétsu-to-Hagané, 67 (1981), 2145.

17) S. Satoh, T. Inoue, N. Masumitsu and K. Kinoshita: Tetsu-to-Hagané, 69 (1983), S180; Trans. ISIJ, 23 (1983), B405.

18) M. Ohtani: Thermodynamics in Iron Metallurgy, Nikkan Kogyo Shinbunsha, Tokyo, (1971), Appendix 1.

19) Handbook on Physical Properties of Molten Iron and Slags, ed. by ISIJ, ISIJ, Tokyo, (1972), 184.

\section{Appendix}

1. Heat of Oxidation of Carbon

$$
\mathrm{C}+\frac{1}{2} \mathrm{O}_{2} \longrightarrow \mathrm{CO} \quad 2450 \mathrm{kcal} / \mathrm{kg}-\mathrm{C}
$$




$$
\mathrm{C}+\mathrm{O}_{2} \longrightarrow \mathrm{CO}_{2} \quad 8080 \mathrm{kcal} / \mathrm{kg}-\mathrm{C}
$$

When the composition of waste gas of LD is assumed to be $\mathrm{CO}=85 \%$ and $\mathrm{CO}_{2}=7.5 \%$, the heat of carbon oxidation is calculated as

$$
\begin{aligned}
& 2450 \times \frac{85}{85+7.5}+8080 \times \frac{7.5}{85+7.5} \\
& =2906 \mathrm{kcal} / \mathrm{kg}-\mathrm{C}
\end{aligned}
$$

from Eqs. (A-1) and (A-2).

Fixed carbon of coke is $87 \%$, so the heat of coke oxidation is

$$
2906 \times 0.87=2528 \mathrm{kcal} / \mathrm{kg}-\text { coke }
$$

2. Sensible Heat of Coke ${ }^{18)}\left(25^{\circ} \mathrm{C} \rightarrow 1600^{\circ} \mathrm{C}\right)$

$$
\begin{gathered}
C_{\mathrm{P}}^{\mathrm{C}}=4.10+1.02 \times 10^{-3} \mathrm{~T}-2.10 \\
\times 10^{5} \times \mathcal{T}^{-2} \mathrm{cal} / \mathrm{mol}^{\circ} \mathrm{K} \\
\int_{298}^{1873} C_{\mathrm{P}} \cdot d T=7.62 \mathrm{kcal} / \mathrm{mol} \\
7.62 \times \frac{1000}{12} \times 0.87=552 \mathrm{kcal} / \mathrm{kg} \cdot \operatorname{coke}
\end{gathered}
$$

\section{Heat of Solution of Carbon ${ }^{19)}$}

$$
\mathrm{C}(\mathrm{s}) \longrightarrow \mathrm{C}(\mathrm{l}) \quad 4.1 \mathrm{kcal} / \mathrm{mol}=297 \mathrm{kcal} / \mathrm{kg} \cdot \operatorname{coke}
$$

4. Sensible Heat of $\mathrm{N}_{2}$ Carrier Gas $\left(25^{\circ} \mathrm{C} \rightarrow 1600^{\circ} \mathrm{C}\right)$

$$
C_{\mathrm{P}}^{\mathrm{N}_{2}}=6.66+1.02 \times 10^{-3} \mathrm{~T} \mathrm{cal} / \mathrm{mol}^{\circ} \mathrm{K}
$$

$$
\int_{298}^{1873} C_{\mathrm{P}} \cdot d T=12.3 \mathrm{kcal} / \mathrm{mol}
$$

As the solid/gas ratio of coke injection is 5 , the sensible heat of $\mathrm{N}_{2}$ for $1 \mathrm{~kg}$ coke injection is

$$
1 \times \frac{1}{5} \times \frac{1}{28} \times 10^{3} \times 12.3=88 \mathrm{kcal} / \mathrm{kg} \cdot \operatorname{coke}
$$

5. Sensible Heat of $\mathrm{O}_{2}\left(25^{\circ} \mathrm{C} \rightarrow 1600^{\circ} \mathrm{C}\right)$

$$
\begin{aligned}
& C_{\mathrm{P}}^{\mathrm{O}_{2}}=7.16 \times 1.00 \times 10^{-3} \times T-0.4 \times 10^{5} \times T^{-2} \\
& \int_{298}^{1873} C_{\mathrm{P}} \cdot d T=13.01 \mathrm{kcal} / \mathrm{mol} \\
& \frac{1000}{32} \times 13.01 \times \frac{16}{12} \times 0.87=472 \mathrm{kcal} / \mathrm{kg} \cdot \mathrm{coke}
\end{aligned}
$$

6. Specific Heat of Steel

$$
210 \mathrm{kcal} / \mathrm{t} \cdot{ }^{\circ} \mathrm{C}
$$

In the case of lump coke addition from vessel top, the amount of heat generated by coke is calculated by Eqs. (A-3) (A-5), (A-7) and (A-8), and is $5.7^{\circ} \mathrm{G} / \mathrm{kg} \cdot$ coke.

In the case of coke breeze injection through vessel bottom, the amount of heat generated by coke is calculated by Eqs. (A-3) to (A-8), and is $5.3^{\circ} \mathrm{C} / \mathrm{kg} \cdot$ coke. 